\title{
Effect of reduced or increased number of pigs born alive at second farrowing on lifetime productivity of sows in southeastern Mexico
}

\author{
Efecto de la reducción o incremento del número de cerdos nacidos vivos en el segundo \\ parto en la vida productiva de las cerdas en el sureste de México
}

JE Ek-Mex*, JC Segura-Correa, A Alzina-López

\begin{abstract}
The objective of this study was to determine the effect of the change in litter size between parity one and two (DNBA) and by summed number of pigs born alive in parity one and two (SNBA) on lifetime productivity of sows in four pig farms in the tropics of Mexico. Data from 6,046 sows, with information on lifetime piglets born alive (LBA), length of productive life (LPL), number of parity at culling (NP) and piglets born alive per year (PBY), were used. Sows were categorised into 11 DNBA groups: $\leq$ $-5,-4,-3,-2,-1,0,+1,+2,+3,+4$ and $\geq+5$ piglets, and 5 SNBA group: $\leq 17,18$ to 20,21 to 22,23 to 25 and $\geq 26$ piglets. A positive linear trend was observed for LBA, LPL and PBY for sows that decreased in $\leq 5$ piglets to sows that increased in $\geq 5$ piglets. Sows with greater SNBA stay longer in the herd and produced more piglets during their productive lifetime. Sows that increased litter size at second parity and those that produce more piglets in their two first parities were more productive.

Key words: piglets, second parity, reproduction, sows.
\end{abstract}

\begin{abstract}
RESUMEN. El objetivo de este estudio fue determinar el efecto del cambio en el tamaño de la camada entre el parto uno y dos (DNBA) y por la suma del número de cerdos nacidos vivos en el parto uno y dos (SNBA) sobre la vida productiva de las cerdas en cuatro granjas porcinas en el trópico de México. Se utilizaron los datos de 6.046 cerdas, con información sobre los lechones nacidos vivos por vida productiva (LBA), la duración de la vida productiva (LPL), número de partos a la eliminación (NP) y lechones nacidos vivos por año (PBY). Las cerdas fueron clasificadas en 11 grupos DNBA: $\leq-5,-4,-3,-2,-1,0,1,2,3,4$ y $\geq 5$ lechones, y 5 del grupo SNBA: $\leq 17$, de 18 a 20, 21 a 22, 23 a 25 y $\geq 26$ lechones. Se observó una tendencia lineal positiva de LBA, LPL y PBY para cerdas que disminuyeron en $\leq 5$ lechones a cerdas que aumentaron en $\geq 5$ lechones. Las cerdas con mayor SNBA permanecen más tiempo en la granja y produjeron más lechones durante su vida productiva. Las cerdas que aumentaron el tamaño de camada al segundo parto y las que tuvieron más lechones en sus dos primeros partos fueron más productivas.

Palabras clave: lechones, segundo parto, reproducción, cerdas.
\end{abstract}

\section{INTRODUCTION}

The number of pigs born alive commonly increases with the parity number of the sow (Suriyasomboon et al 2006). However, Morrow et al (1992) in USA reported that $41 \%$ of the herds and $54 \%$ of the sows show a decrease or similar number of piglets born alive in the second parity compared to the first parity sows, phenomenon called the second-litter syndrome. In the tropics of Mexico, the percentages of sows showing the second-litter syndrome are 60\% (Segura-Correa et al 2013). The reduction in litter size at second parity might decrease lifetime productivity (Hoving et al 2011). The decrease or increase in litter size at second parity is binomial trait; however, litter size decrease in parity 2 sows (Sasaki et al 2011). The summed number of pigs born alive in parities 1 and 2 (SNBA) is an alternative measure of prolificacy of sows and it was reported to be related with a reduction of the number of

Accepted: 10.12.2015.

Campus de Ciencias Biológicas y Agropecuarias, Universidad Autónoma de Yucatán, Mérida, Yucatán, México.

*Corresponding author: JE Ek-Mex, Km 15.5 carretera Mérida-Xmatkuil, Mérida, Yucatán, México; jeemvz@hotmail.com piglets born alive in parity two at the sow level (Saito et al 2010). Furthermore, Sasaki et al (2011) reported the effect of quantitative difference in the number of piglets born alive between parity one and two (DNBA) and SNBA on lifetime piglets born alive, lifetime nonproductive days, and number of parity at culling and piglets born alive per sow per year.

A few studies have reported on the effect of DNBA and SNBA on lifetime productivity of sows (Saito et al 2010, Sasaki et al 2011) and none in tropical conditions. It might be possible to increase reproductive and productive performance of sows and herds by determining the critical value of DNBA and SNBA for sow lifetime performance, which may help in making decisions and choose management practices that increase the amount of pigs born alive in swine production systems. The objective of this study is to determine the effect of DNBA and by SNBA on lifetime productivity of sows in four pig farms in the tropics of Mexico.

\section{MATERIAL AND METHODS}

Data was collected from four typical commercial farms of Yucatan, Mexico, located between $19^{\circ} 30^{\prime}$ and $21^{\circ} 35^{\prime}$ North and $90^{\circ} 24^{\prime}$ 'West,. The climate of the region is 
sub-humid tropical, with average temperature of $26.6^{\circ} \mathrm{C}$, average rainfall of $1.100 \mathrm{~mm}$, and relative humidity of $78 \%$ (INEGI 2004). The data from the farms used in this study had been previously used in another study about lifetime performance of sows (Ek-Mex et al 2015). Data were obtained from the computer recording system (PigCHAMP ®) of the four farms from 2007 to 2011. The main information used was farm identification, sow identification, sow parity number, date of farrowing and litter size at farrowing. All farmers had sows Camborough 22 , produced their own replacements and quarantine the replacement gilts.

Farms 1, 2 and 4 were full cycle farms with 3.900, 1.200 and 550 sows, respectively. Farm 3 was a two-sitetype farm (breeding and production) with 320 sows. In all farms, breeding was carried out by artificial insemination; however, if sows did not get pregnant after three inseminations, natural mating with a boar was used. Estrus detection in sows was performed every day at 6:00 and 18:00 h using a boar, and sows inseminated two times (12:00-18:00 h), after estrus detection. Animals were fed commercial diets according to their productive stage. Young sows (about $200 \mathrm{~kg}$ body weight) received $2.6 \mathrm{~kg}$ / day of feed with $3.000 \mathrm{kcal} \mathrm{EM} / \mathrm{kg}, 16 \%$ crude protein and $0.8 \%$ lysine; whereas adult sows over $300 \mathrm{~kg}$ of weight received $3.2 \mathrm{~kg} /$ day of feed.

DNBA was calculated by subtracting the number of piglets born alive in the first parity from the number of piglets born alive in the second parity (Sasaki et al 2011). SNBA was defined as the sum of the number of piglets born alive in the first and second parity (Saito et al 2010). Lifetime productivity was calculated as the total number of piglets born alive (LBA) from first to last farrowing. The length of productive life (LPL) was defined as the time from the first farrowing to culling or death of the sow. The productivity per year was defined as the number of piglets born alive per sow per year (PBY). PBY was calculated as LBA divided by the total days from entry date and removed or culling date from the breeding herd multiplied by 365 days; when the total days from entry date and removed or culling date was $\leq 365$ days, the PBY of a sow was equal to the LBA (Ek-Mex et al 2015). Based on DNBA sows were categorised into eleven groups: $\leq-5,-4,-3,-2,-1,0$, $+1,+2,+3,+4$ and $\geq+5$ piglets. Five SNBA groups were built based on quintiles: $\leq 17,18$ to 20,21 to 22,23 to 25 and $\geq 26$ piglets.

The statistical analyses were carried out using general linear model procedures (SAS 2008). Two models were used; in both models, the dependent variables were LBA, LPL, number of parities per sow (NP), and PBY. The first statistical model included the fixed effects of DNBA, farm $(1,2,3,4)$, year of first farrowing (2007 to 2011), season of first farrowing (dry, rainy and windy), litter size at first farrowing (LSF1), age at first farrowing (AF1), significant simple interactions and the error term NID (normal identically distributed; $0, \sigma^{2} \mathrm{e}$ ). The second model was similar to model 1 except that the effect of DNBA was replaced by the effect of SNBA. The season of first farrowing was not significant on PBY in Model 1; and LSF1 was not significant on LPL and NP in Model 2, so they were removed from the final analysis. In addition, the fixed effects of year at first farrowing, season at first farrowing, LSF1 and AF1 were not included in the results. Least square means were generated and separated statistically with pairwise $t$ tests (PDIFF option), with significant differences reported at $\mathrm{P} \leq 0.05$. Correlation analysis was carried out between LBA and PBY using the CORR procedure (SAS 2008).

\section{RESULTS AND DISCUSSION}

The overall mean and standard deviation of DNBA was $-0.41 \pm 4.0$ pigs, the means and standard deviation for farm $1,2,3$ and 4 was $-0.53 \pm 4.1,-0.5 \pm 4.0$, and $0.12 \pm 3.5$ and $0.16 \pm 3.6$ piglets, respectively. The means overall and for farm of DNBA in this study was low that reported by Sasaki et al, (2011) of 0.5 piglets. The frequencies (\%) of the DNBA groups $(\leq-5,-4,-3,-2,-1,0,+1,+2,+3,+4$ or $\geq$ +5 piglets) were $15.1,5.4,6.8,9.5,10.2,11.3,10.5,8.6$, $6.9,5.4$ and $9.9 \%$, respectively. The $20.6 \%$ of sows had litter size reduced in at least 4 piglets from first to second parity, which also had the worst lifetime performance. A positive linear trend was observed for LBA, LPL, PBY and NP for sows that decreased in $\leq-5$ piglets to sows that increased in $\geq+5$ piglets (table 1 ). The greatest LBA and PBY were observed for the sows with DNBA between -1 to $\geq+5$ piglets; which differ from that reported by Sasaki et al (2011) who reported the greatest LBA and PBY in sows with DNBA -1 to +3 piglets. Also, in this study the simple correlation of LBA and PBY was 0.63. A decrease in the number of piglets born alive at second parity might also decrease lifetime performance (Hoving et al 2011). The reduction of the number of piglets born alive in second parity might be related to large litter size at first parity (Saito et al 2009, Segura-Correa et al 2013). Likewise, the decrease of litter size in second parity sows is often related to an excessive weight loss during first lactation and short weaning to oestrous interval can negatively influence follicle and oocyte development and embryonic survival (Schenkel et al 2010). The increased the number of piglets born alive in parity 2 may be due in part by the prolonged weaning to first service interval and farrowing interval (Koketsu et al 1998, Alzina-López et al 2011). Also, these differences may be due to administration decisions, differences in biosecurity measures, genetic lines used, the size of the herd and statistical model used. Differences in production per year could also be due the factors mentioned before. Likewise, management practices, inefficient estrous detection, improper male stimulation, mating at an early age, uses of young boars, improper nutrition, infectious or toxic agents, and environment can be responsible for these differences.

The means and standard deviations of SNBA were $21.1 \pm 4.6$ piglets, the means and standard deviation for 
Table 1. Least squares means and standard errors by sow groups based on the difference of number of pigs born alive between parity 1 and 2 (DNBA), and between the sum of number of pigs born alive in parity 1 and 2 (SNBA).

Medias de cuadrados medios y error estándar por grupo de cerdas grupos de cerdas basada en la diferencia del número de lechones nacidos vivos entre el parto 1 y 2 (DNBA), y entre la suma de numero de lechones nacidos vivos en el parto 1 y 2 (SNBA).

\begin{tabular}{cccccc}
\hline Sow groups & $\mathrm{N}$ & LBA & LPL & NP & PBY \\
\hline DNBA & & & & & \\
$\leq-5$ & 915 & $39.2 \pm 1.82^{\mathrm{f}}$ & $601.6 \pm 19.1^{\mathrm{c}}$ & $4.6 \pm 0.15^{\mathrm{b}}$ & $17.4 \pm 0.33^{\mathrm{i}}$ \\
-4 & 331 & $44.5 \pm 2.02^{\mathrm{e}}$ & $626.3 \pm 21.8 \mathrm{~b}^{\mathrm{c}}$ & $4.8 \pm 0.17^{\mathrm{ab}}$ & $19.9 \pm 0.37^{\mathrm{h}}$ \\
-3 & 415 & $43.5 \pm 1.9^{\mathrm{e}}$ & $606.3 \pm 21^{\mathrm{c}}$ & $4.6 \pm 0.16^{\mathrm{b}}$ & $20.2 \pm 0.36^{\mathrm{gh}}$ \\
-2 & 579 & $45.6 \pm 1.9^{\mathrm{e}}$ & $617.3 \pm 20.2^{\mathrm{c}}$ & $4.7 \pm 0.16^{\mathrm{b}}$ & $20.6 \pm 0.35^{\mathrm{g}}$ \\
-1 & 616 & $48.8 \pm 1.9^{\mathrm{d}}$ & $640.6 \pm 20.2^{\mathrm{ab}}$ & $4.9 \pm 0.16^{\mathrm{a}}$ & $21.7 \pm 0.34^{\mathrm{f}}$ \\
0 & 685 & $50.4 \pm 1.9^{\mathrm{d}}$ & $647.4 \pm 20^{\mathrm{ab}}$ & $4.9 \pm 0.15^{\mathrm{a}}$ & $22.4 \pm 0.34^{\mathrm{e}}$ \\
+1 & 636 & $53.5 \pm 1.9^{\mathrm{c}}$ & $660.7 \pm 20^{\mathrm{a}}$ & $5 \pm 0.16^{\mathrm{a}}$ & $23.4 \pm 0.34^{\mathrm{d}}$ \\
+2 & 522 & $53.3 \pm 1.9^{\mathrm{c}}$ & $646 \pm 20.4^{\mathrm{ab}}$ & $4.9 \pm 0.16^{\mathrm{a}}$ & $23.9 \pm 0.35^{\mathrm{c}}$ \\
+3 & 417 & $54.6 \pm 1.9^{\mathrm{bc}}$ & $658.8 \pm 21^{\mathrm{ab}}$ & $5.0 \pm 0.16^{\mathrm{a}}$ & $24.3 \pm 0.36^{\mathrm{c}}$ \\
+4 & 329 & $56.8 \pm 2.01^{\mathrm{b}}$ & $660.9 \pm 22^{\mathrm{ab}}$ & $4.9 \pm 0.17^{\mathrm{a}}$ & $25.5 \pm 0.37^{\mathrm{b}}$ \\
$\geq+5$ & 602 & $60 \pm 1.9^{\mathrm{a}}$ & $661.9 \pm 20^{\mathrm{a}}$ & $4.9 \pm 0.15^{\mathrm{a}}$ & $27.2 \pm 0.34^{\mathrm{a}}$ \\
SNBA & & & & \\
$\leq 17$ & 1.295 & $40.2 \pm 1.6^{\mathrm{e}}$ & $603.9 \pm 11.4^{\mathrm{d}}$ & $4.5 \pm 0.08^{\mathrm{c}}$ & $17.6 \pm 0.33^{\mathrm{f}}$ \\
$18-20$ & 1.287 & $47.2 \pm 1.6^{\mathrm{d}}$ & $632.9 \pm 11.3^{\mathrm{c}}$ & $4.7 \pm 0.08^{\mathrm{b}}$ & $20.8 \pm 0.33^{\mathrm{d}}$ \\
$21-22$ & 1.079 & $51.2 \pm 1.6^{\mathrm{c}}$ & $642.4 \pm 11.8^{\mathrm{bc}}$ & $4.8 \pm 0.08^{\mathrm{ab}}$ & $22.6 \pm 0.34^{\mathrm{c}}$ \\
$23-25$ & 1.348 & $55.0 \pm 1.6^{\mathrm{b}}$ & $660.9 \pm 11.1^{\mathrm{a}}$ & $4.9 \pm 0.08^{\mathrm{a}}$ & $24.1 \pm 0.33^{\mathrm{b}}$ \\
$\geq 26$ & 1.037 & $59.2 \pm 1.6^{\mathrm{a}}$ & $657.0 \pm 11.8^{\mathrm{ab}}$ & $4.9 \pm 0.08^{\mathrm{a}}$ & $26.4 \pm 0.33^{\mathrm{a}}$ \\
\hline
\end{tabular}

Column with different letters are statistically different $(\mathrm{P}<0.05)$. LBA: lifetime of piglets born alive. LPL: length of productive life. NP: number of parities per sow. PBY: piglets born alive per sow per year.

Columna con diferente literal son estadísticamente diferentes $(\mathrm{P}<0,05)$. LBA: lechones nacidos vivos por vida productiva. LPL: duración de la vida productiva. NP: número de partos a la eliminación. PBY: lechones nacidos vivos por cerda por año.

farm $1,2,3$ and 4 were $21.4 \pm 4.5,22.7 \pm 5.1,19 \pm 4.2$ y $18.8 \pm 4$, respectively. Sows with more SNBA had better performance for all four traits. The sows with SNBA $\geq 26$ pigs had 8.4 pigs more $\mathrm{PBY}$ than sows with $\mathrm{SNBA} \leq 17$ pigs. In our study, the sows with high SNBA ( $\geq 23$ pigs) had the highest lifetime performance (table 1). According to Sasaki et al (2011) lifetime productivity after parity 2 could partly be predicted by SNBA. The repeatabilities for litter size is low of 0.12 (Segura-Correa et al 2015), which indicated a high influence of environmental factors associated with small litter size at second parity such as large litter size at first parity, body condition score, lactation length and weaning to service interval (Saito et al 2009, Schenkel et al 2010, Segura-Correa et al 2013). Therefore, better management practices are needed to improve litter size at farrowing in young sows.

Under the conditions of this study, sows with large decrease in liters size at second parity had the poorest lifetime performance; and sows with more SNBA piglets had the greatest lifetime performance at farrowing. As an alternative, culling of sows based on poor DNBA and SNBA performance could improve lifetime productivity of sow. However, culling a sow immediately at the second parity may increase PBY of the sow, but decrease the lifetime piglets of born alive and the number of parities per sow of the farm. Also, salvaged prices for young sows at parity 2 may not cover replacement gilt costs unless the market price for culled sows is so high.

\section{REFERENCES}

Alzina-López A, A Pérez-Villegas, J Segura-Correa. 2011. Efecto de la inseminación al primer celo postdestete o la aplicación de gonadotropinas e inseminación al segundo celo en el tamaño de camada de cerdas primerizas. Trop Subtrop Agroecosyst 14, 295-299.

Ek-mex J, J Segura-Correa, A Alzina-López, L Batista-García. 2015. Lifetime and per year productivity of sows in four pig farms in the tropics of Mexico. Trop Anim Health Prod 47, 503-509.

Hoving L, N Soede, E Graat, H Feitsma, B Kemp. 2011. Reproductive performance of second parity sows: Relations with subsequent reproduction. Livest Sci 140, 124-130.

INEGI, Instituto Nacional de Estadística, Geografía e Informática. 2004. Anuario Estadístico de Yucatán. INEGI, México, D.F.

Koketsu Y, G Dial, J Pettigrew, J Xue, H Yang, T Lucia. 1998. Influence of lactation length and feed intake on reproductive performance and blood concentrations of glucose, insulin and luteinizing hormone in primiparous sows. Anim Reprod Sci 52, 153-163.

Morrow W, A Leman, N Williamson, R Morrison, R Robinson.1992. An epidemiological investigation of reduced second-litter size in swine. Prev Vet Med 12, 15-26.

Saito H, Y Koketsu. 2009. Factors associated with an occurrence of decreased pigs born alive in parity 2 in commercial herds. $J$ Vet Epidemiol 13, 40-45. 
Saito H, Y Sasaki, Y Hoshino, Y Koketsu. 2010. The occurrence of decreased numbers of pigs born alive in parity 2 sows does not negatively affect herd productivity in Japan. Livest Sci 128, 189-192.

SAS, Statistical Analysis System Institute. 2008. SAS/STAT User's Guide (Release 9.2). SAS Inst. Inc., Cary NC, USA.

Sasaki Y, Koketsu Y. 2008. Sows having high lifetime efficiency and high longevity associated with herd productivity in commercial herds. Livest Sci 118, 140-146.

Sasaki Y, H Saito, A Shimomura, Y Koketsu. 2011. Consecutive reproductive performance after parity 2 and lifetime performance in sows that had reduced pigs born alive from parity 1 to 2 in Japanese commercial herds. Livest Sci 139, 252-257.
Schenkel A, M Bernardi, F Bortolozzo, I Wentz. 2010. Body reserve mobilization during lactation in first parity sows and its effect on second litter size. Livest Sci 132, 165-172.

Segura-Correa J, R Santos-Ricalde, J Rodríguez-Buenfil. 2013. Risk factors associated with the second-litter syndrome under the tropical conditions of Mexico. Livest Res Rural Dev 25, 1-7.

Segura-Correa J, J Herrera-Camacho, R Pérez-Sánchez, Ernestina GutiérrezVázquez. 2015. Breed and environmental factors of sows and their repeatabilities in central Mexico. Rev Colomb Cienc Pecu 28, 13-21.

Suriyasomboon A, N Lundeheim, A Kunavongkrit, S Einarsson. 2006. Effect of temperature and humidity on reproductive performance of crossbred sows in Thailand. Theriogenology 65, 606-628. 